\title{
WIEDZA SZCZECINIAN NA TEMAT CHORÓB RZADKICH
}

\section{SZCZECIN CITIZENS' KNOWLEDGE ABOUT RARE DISEASES}

\author{
Studenckie Koło Naukowe Chorób Rzadkich Pomorskiego Uniwersytetu Medycznego w Szczecinie \\ przy Klinice Patologii Noworodka i Zakładzie Diagnostyki Obrazowej i Radiologii Interwencyjnej \\ al. Powstańców Wlkp. 72, 70-111 Szczecin \\ Opiekunowie: prof. dr hab. n. med. Jacek Rudnicki, prof. dr hab. n. med. Anna Walecka, \\ dr n. med. Marcin Sawicki, lek. Michat Skoczylas
}

\section{Summary}

Introduction: The aim of the study was to assess knowledge about rare diseases among citizens of Szczecin (Poland).

Material and methods: The study was performed by questioning 242 adult customers of Turzyn Shopping Centre in Szczecin (149 females and 93 males). The survey was conducted in the shopping mall on 23 February 2013 (control group) and during the celebration of Rare Disease Day and the $12^{\text {th }}$ Polish Nationwide Cystic Fibrosis Week ("Dolina Mukolinków") on 2 March 2013 (research group). The research tool was a questionnaire devised by the authors and filled out by the writing authors interviewer's answers.

Results: In the study group more people knew about the existence of Rare Disease Day than in the control group ( $86.02 \%$ vs $57.72 \%$, chi-square test $\left.\chi^{2}>\chi_{1 ; 0.001}^{2}, \mathrm{p}<0.001\right)$, but there was no significant difference between knowledge of when Rare Disease Day is celebrated. The definition of rare diseases compatible with the definition of the European Commission's Health and Consumer Protection was reported only in the control group by 4 people. Examples of rare diseases were reported by $74.19 \%$ of the respondents in the study group and by $65.10 \%$ in the control group (more than 130 diseases were mentioned altogether). Usually, respondents mentioned fewer examples than were asked about in the questionnaire. The aim of Rare Disease Day was accurately specified by $86.02 \%$ of persons in the study group and $87.92 \%$ in the control group. Rare Disease Day personally concerns $30.11 \%$ of respondents in the study group and $10.07 \%$ of persons in the control group $(\mathrm{OR}=3.85$, $95 \%$ CI $\left.0.9-3.6, \chi^{2}>\chi_{1 ; 0.001}^{2}, \mathrm{p}<0.001\right)$.
Conclusions: The respondents from the research group knew more about Rare Disease Day and defined the idea of it as closed in a significantly higher degree than the control group. There was no significant difference in the detailed knowledge about rare diseases in either group. This might indicate the need to educate society and patients, along with their families.

Key words: rare diseases - Rare Disease Day questionnaire study.

\section{Streszczenie}

Wstęp: Celem pracy była ocena wiedzy szczecinian na temat chorób rzadkich.

Materiat $i$ metody: Badaniem objęto 242 osoby (149 kobiet $i 93$ mężczyzn). Badanie ankietowe z zastosowaniem metody sondażu diagnostycznego przeprowadzono w Galerii Handlowej Turzyn w Szczecinie 23 lutego 2013 r. (grupa kontrolna) oraz podczas obchodów Dnia Chorób Rzadkich i XII Ogólnopolskiego Tygodnia Mukowiscydozy 2 marca 2013 r. (grupa badana). Kwestionariusze były wypełniane przez autorów na podstawie wypowiedzi ankietowanych.

Wyniki: W grupie badanej więcej osób wiedziało o istnieniu Dnia Chorób Rzadkich niż w grupie kontrolnej $\left(86,02 \%\right.$ vs $57,72 \%$, test chi-kwadrat $\left.\chi^{2}>\chi_{1 ; 0,001}^{2}, p<0,001\right)$, lecz nie wykazano istotnej różnicy co do wiedzy na temat tego, kiedy jest on obchodzony. Definicję choroby rzadkiej zgodną z definicją Komisji Europejskiej ds. Zdrowia i Ochrony Konsumentów podały wyłącznie 4 osoby z grupy kontrolnej. Przykłady chorób rzadkich w grupie badanej 
podało 74,19\% ankietowanych, a w kontrolnej 65,10\% (łącznie ponad 130 jednostek chorobowych). Pomimo że proszono o podanie trzech chorób, zwykle ankietowani wymieniali mniejszą liczbę przykładów. Cel Dnia Chorób Rzadkich trafnie sprecyzowało $86,02 \%$ osób z grupy badanej i 87,92\% osób z grupy kontrolnej. Jest on bliski dla 30,11\% osób z grupy badanej i 10,07\% osób z grupy kontrolnej $\left(\mathrm{OR}=3,85 ; 95 \%\right.$ CI $\left.0,9-3,6 ; \chi^{2}>\chi_{1 ; 0,001}^{2}, \mathrm{p}<0,001\right)$.

Wnioski: Respondenci z grupy badanej wiedzieli o obchodach Dnia Chorób Rzadkich i określali jego ideę jako bliską w stopniu istotnie wyższym niż w grupie kontrolnej. Brak znaczących różnic dotyczących wiedzy szczegółowej w skali obu grup wskazuje na potrzebę edukowania całego społeczeństwa oraz chorych i ich rodzin.

H a s $\nmid$ a: choroby rzadkie - Dzień Chorób Rzadkich - badanie ankietowe.

\section{Wstęp}

Według Komisji Europejskiej ds. Zdrowia i Ochrony Konsumentów choroby rzadkie to choroby przewlekłe o poważnym i wyniszczającym przebiegu, które występują rzadziej niż 5:10 000 w danym społeczeństwie [1]. Najczęściej są to choroby uwarunkowane genetycznie, ujawniające się zazwyczaj w wieku dziecięcym, choć niektóre dopiero w okresie dojrzewania lub dorosłości; 75\% chorych stanowią dzieci. W Europie $\mathrm{z}$ ich powodu cierpi ok. $30 \mathrm{mln}$ ludzi [2]. Dane te są prawdopodobnie niedoszacowane. Pomimo że do tej pory wydzielono ok. 5-8 tys. rzadkich jednostek chorobowych, a kolejne są opisywane w literaturze medycznej [3, 4], to wiedza na ich temat wciąż jest znikoma.

Chorym trudno znaleźć informacje na temat ich chorób oraz specjalistyczną pomoc. Czują się odizolowani od społeczeństwa. Odpowiednie leczenie przyczynowe i objawowe oraz zapobieganie powikłaniom chorób mogą poprawić jakość życia oraz wydłużyć czas życia osób przewlekle chorych. W wielu placówkach medycznych odpowiednie badania diagnostyczne nie są dostępne. Znaczący postęp, jaki dokonał się w zakresie leczenia niektórych chorób, dowodzi, że warto kontynuować wysiłek wkładany w badania naukowe.

Choroby te dotykają nie tylko pacjenta, lecz także jego rodzinę, przyjaciół i całe społeczeństwo. Aby wyjść z pomocą osobom chorym i ich rodzinom, a także naświetlić problem dla przedstawicieli środowisk medycznych, powstają fundacje charytatywne oraz organizowane są akcje informacyjne, jak np. Dzień Chorób Rzadkich (Rare Disease Day-DzChRz). Poprzez edukację społeczeństwa budowana jest akceptacja i zrozumienie dla chorych oraz ich rodzin. Dzięki nagłaśnianiu problemu znajdują się także osoby, które chcą pomagać. Symbolem wsparcia dla osób cierpiących na choroby rzadkie w Polsce stała się dżinsowa wstążka, ponieważ choroby rzadkie najczęściej są powodowane wadami genetycznymi, a w języku angielskim słowo geny (gens) jest wymawiane tak samo jak dżins, tkanina denim (ang. jeans z wymową od francuskiej nazwy włoskiego miasta Genua, Gênes) [5]. Jednym z najlepiej przygotowanych źródeł wiedzy na temat chorób rzadkich, badań prowadzonych nad nimi oraz stowarzyszeń wzajemnej pomocy chorych jest portal internetowy Orpha.net [6].

Dzień Chorób Rzadkich został ustanowiony przez Europejską Federację Rodziców Pacjentów i Pacjentów z rozpoznaniem chorób rzadkich EURORDIS i odbył się po raz pierwszy w 2008 r. [7]. Celem tej inicjatywy jest uświadamianie społeczeństwa, informowanie, nagłaśnianie problemu chorób rzadkich, a także pomoc chorym i ich rodzinom. W 2013 r. w Polsce DzChRz był zorganizowany po raz trzeci. Jest on obchodzony na całym świecie w ostatni dzień lutego - co 4 lata 29 lutego (najrzadziej występujący dzień w kalendarzu), a w latach nieprzestępnych 28 lutego.

Problematyka chorób rzadkich nie jest dobrze znana ogółowi społeczeństwa. Chorzy na choroby sieroce od lat walczą z problemem niewiedzy na temat swoich chorób i brakiem odpowiednich regulacji prawnych dotyczących leczenia oraz codziennej opieki. W celu oceny wiedzy społeczeństwa nt. chorób rzadkich podczas obchodów Dnia Chorób Rzadkich i Doliny Mukolinków, wśród klientów Galerii Handlowej Turzyn (G.H. Turzyn) przeprowadzono badanie ankietowe.

\section{Material i metody}

Badaniem ankietowym zostały objęte 93 osoby w grupie badanej i 149 osób w grupie kontrolnej. W badaniu wzięli udział przypadkowo spotkani klienci G.H. Turzyn w Szczecinie, którzy ukończyli 18. r.ż. oraz ustnie wyrazili zgodę na wzięcie udziału w badaniu po otrzymaniu zapewnienia anonimowości i informacji o wykorzystaniu wyników badań tylko do celów naukowych. Ankietowani stanowiący grupę badaną byli klientami G.H. Turzyn 2 marca 2013 r., czyli w dniu, kiedy odbywała się akcja „Dolina Mukolinków”, będąca częścią XII Ogólnopolskiego Tygodnia Mukowiscydozy organizowanego przez Fundację Pomocy Rodzinom i Chorym na Mukowiscydozę MATIO. Osoby badane w obu grupach reprezentowały różne zawody. Stosunkowo dużo było uczniów i studentów - $50(33,56 \%)$ osób w grupie kontrolnej oraz 35 (37,63\%) w grupie badanej. Osoby pracujące w zawodach medycznych, które mogłyby mieć wiedzę o chorobach rzadkich pochodzącą z własnej praktyki zawodowej, stanowiły tylko ok. 4,3\% w grupie badanej i 3,36\% w grupie kontrolnej. Charakterystykę obu grup przedstawiono w tabeli 1.

Wywiady autorów z ankietowanymi odbyły się 2 dni po obchodzonym w wielu krajach Dniu Chorób Rzadkich. Badanie grupy kontrolnej przeprowadzono 23 lutego $2013 \mathrm{r}$., tj. na tydzień przed akcją „Dolina Mukolinków” i 5 dni przed Dniem Chorób Rzadkich.

Badanie przeprowadzono za pomocą autorskiego kwestionariusza (tab. 2) składającego się z 5 pytań merytorycznych 
T a b e la 1 . Charakterystyka respondentów

Grupa badana (93 osoby)

\begin{tabular}{|c|c|c|}
\hline \multicolumn{3}{|c|}{ Grupa badana (93 osoby) } \\
\hline Wiek & kobiety & mężczyźni \\
\hline$\leq 20$ & 7 & 4 \\
\hline $21-30$ & 23 & 10 \\
\hline $31-40$ & 15 & 7 \\
\hline $41-50$ & 5 & 7 \\
\hline$\geq 51$ & 12 & 3 \\
\hline Razem (osób) & $62(66,67 \%)$ & $31(33,33 \%)$ \\
\hline Średni wiek (w latach) & 34,47 & 34,55 \\
\hline \multicolumn{3}{|c|}{ Grupa kontrolna (149 osób) } \\
\hline Wiek & kobiety & mężczyźni \\
\hline$\leq 20$ & 3 & 6 \\
\hline $21-30$ & 40 & 20 \\
\hline $31-40$ & 14 & 10 \\
\hline $41-50$ & 14 & 6 \\
\hline$\geq 51$ & 16 & 20 \\
\hline Razem (osób) & $87(58,39 \%)$ & $62(41,61 \%)$ \\
\hline Średni wiek (w latach) & 36,37 & 41,81 \\
\hline
\end{tabular}

oraz pytań o dane demograficzne. Pytania merytoryczne dotyczyły chorób rzadkich i Dnia Chorób Rzadkich. Wszystkie informacje były zbierane i zapisywane wyłącznie przez ankieterów.

Dla uproszczenia osoby ankietowane są określone jako szczecinianie, chociaż kwestionariusz nie zawierał pytania o miejsce zamieszkania.

\section{Wyniki}

Za poprawną odpowiedź na pytanie o termin Dnia Chorób Rzadkich uznawano zarówno właściwą datę 29 lutego, jak i 28 lutego, ponieważ w latach nieprzestępnych dzień ten jest obchodzony w ostatnim dniu tego miesiąca. W grupie badanej poprawnie odpowiedziało 14 (22,58\%) kobiet i $4(12,9 \%)$ mężczyzn. Poprawne odpowiedzi zostały udzielone w 19,35\% wywiadów. Brak odpowiedzi lub odpowiedzi nieprawidłowe stanowiły 80,65\%. W grupie kontrolnej poprawnie odpowiedziało 13 (14,94\%) kobiet i 7 (11,29\%) mężczyzn. Poprawne odpowiedzi stanowiły $13,42 \%$ vs $86,58 \%$, tj. brak odpowiedzi oraz odpowiedzi nieprawidłowe. Zatem różnica między liczbami odpowiedzi poprawnych w grupie badanej i grupie kontrolnej w odniesieniu do liczebności tych grup może być wyrażona w odsetkach jako różnica między $19,35 \%$ a $13,42 \%$, lecz poziom istotności w teście $\chi^{2}>0,2$.

W grupie badanej więcej osób wiedziało o istnieniu Dnia Chorób Rzadkich niż w grupie kontrolnej (86,02\% vs $57,72 \%$, test chi-kwadrat $\left.\chi^{2}>\chi_{1 ; 0,001}^{2}, \mathrm{p}<0,001\right)$ - tabela 3 . Ponad połowa wszystkich ankietowanych wcześniej dowiedziała się o Dniu Chorób Rzadkich od innych osób lub z przekazów mediów. Z tego znaczna grupa osób, 46,98\% grupy kontrolnej i 45,16\% grupy badanej dowiedziała się podczas obchodów Dnia Chorób Rzadkich w G.H. Turzyn, co może wskazywać na duże znaczenie prowadzenia tego typu akcji informacyjnych. Inne wymieniane źródła wiedzy to Internet, telewizja i plakaty.

Odpowiedzi na pytanie o definicję choroby rzadkiej nie udzieliły 42 (28,19\%) osoby z grupy kontrolnej i 30 $(32,26 \%)$ osób z grupy badanej. Prawidłowej odpowiedzi , $<1: 2000$ " (lub równoznacznych) udzieliły tylko 4 (2,68\%) osoby z grupy kontrolnej. Nikt z grupy badanej nie udzielił poprawnej odpowiedzi. Zwykle określano te choroby jako rzadko występujące, bez podania dokładnej częstości lub podawano częstość rzadszą niż jest przyjęta w definicji Komisji Europejskiej ds. Zdrowia i Ochrony Konsumentów. Niższą niż ustalona w definicji częstość podało 28 (18,79\%) osób z grupy kontrolnej i 10 (10,75\%) z grupy badanej. Inne podawane odpowiedzi to choroba wrodzona, uwarunkowana genetycznie lub trudna w leczeniu.

T a b e 1 a 2. Kwestionariusz

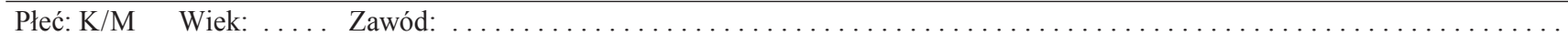

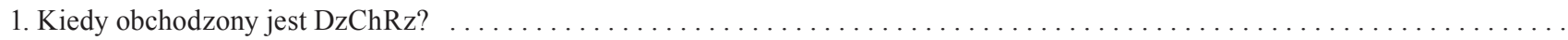

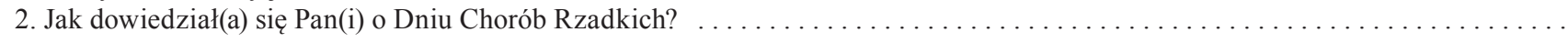

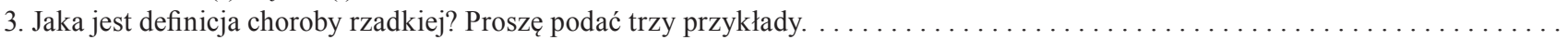

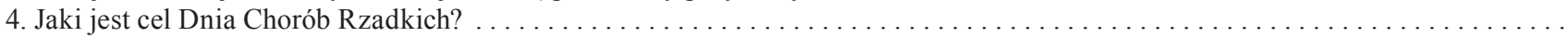

5. Czy DzChRz jest bliski dla Pani/Pana lub Pani/Pana rodziny? Tak/Nie . . . . . . . . . . . . . . . . . . . . . . . . .

DzChRz - Dzień Chorób Rzadkich

T a b e la 3. Wiedza o Dniu Chorób Rzadkich (DChRz)

\begin{tabular}{|c|c|c|c|c|c|c|}
\hline \multicolumn{7}{|c|}{ Grupa badana } \\
\hline Wiedza o DChRz & \multicolumn{2}{|c|}{ kobiety } & \multicolumn{2}{|c|}{ mężczyźni } & \multicolumn{2}{|c|}{ ogółem } \\
\hline Przed wywiadem & 53 & $85,48 \%$ & 27 & $87,10 \%$ & 80 & $86,02 \%$ \\
\hline Brak & 9 & $14,52 \%$ & 4 & $12,90 \%$ & 13 & $13,98 \%$ \\
\hline \multicolumn{7}{|c|}{ Grupa kontrolna } \\
\hline Wiedza o DChRz & \multicolumn{2}{|c|}{ kobiety } & \multicolumn{2}{|c|}{ mężczyźni } & \multicolumn{2}{|c|}{ ogółem } \\
\hline Przed wywiadem & 54 & $62,07 \%$ & 32 & $51,61 \%$ & 86 & $57,72 \%$ \\
\hline Brak & 33 & $37,93 \%$ & 30 & $48,39 \%$ & 63 & $42,28 \%$ \\
\hline
\end{tabular}


Przykłady chorób rzadkich $\mathrm{w}$ grupie kontrolnej podało 97 (65,10\%) osób, a w grupie badanej 69 (74,19\%). Pomimo że proszono o wymienienie 3 chorób, zwykle ankietowani wymieniali mniejszą liczbę przykładów (tab. 4).

$$
\text { T a b e } 1 \text { a 4. Przykłady chorób rzadkich }
$$

\begin{tabular}{ccccc} 
& \multicolumn{2}{c}{ Grupa badana } & \multicolumn{2}{c}{ Grupa kontrolna } \\
\cline { 2 - 5 } & kobiety & mężczyźni & kobiety & mężczyźni \\
\hline 0 & 16 & 8 & 28 & 24 \\
\hline 1 & 20 & 12 & 23 & 15 \\
\hline 2 & 8 & 5 & 8 & 7 \\
\hline 3 & 15 & 4 & 27 & 16 \\
\hline$>3$ & 3 & 2 & 1 & 0 \\
\hline
\end{tabular}

Łącznie podano nazwy ponad 130 jednostek chorobowych. Około $45 \%$ z nich stanowiły prawidłowo podane nazwy chorób rzadkich. Najczęstsze spośród prawidłowo wymienianych chorób w grupie badanej i grupie kontrolnej to mukowiscydoza, fenyloketonuria i zespół Turnera (tab. 5). Choroby bardzo rzadkie wymieniały pojedyncze osoby. Były to na przykład: zespół Klinefeltera, zespół Retta, zespół Patau, zespół Sturge-Webera, zespół Piersona, mukopolisacharydoza, ichtiosis, zespół Di George’a, wrodzona łamliwość kości, kwasica glutarowa typu I, choroba Alpersa i choroba von Gierkego.

T a b e 1 a 5 . Najczęściej wymieniane choroby rzadkie (przez $\geq \mathbf{5}$ osób)

\begin{tabular}{ll}
\multicolumn{2}{c}{ Grupa badana } \\
\hline Mukowiscydoza & 58 \\
\hline Fenyloketonuria & 15 \\
\hline & Grupa kontrolna \\
\hline Mukowiscydoza & 26 \\
\hline Progeria & 6 \\
\hline Choroba moyamoya & 5 \\
\hline Fenyloketonuria & 5 \\
\hline Zespół Turnera & 5 \\
\hline
\end{tabular}

Cel Dnia Chorób Rzadkich trafnie sprecyzowało 131 $(87,92 \%)$ osób z grupy kontrolnej oraz $80(86,02 \%)$ z grupy badanej. Niewielu ankietowanych nie znało odpowiedzi i nie starało się jej podać: 18 (12,08\%) osób z grupy kontrolnej i $13(13,98 \%)$ z grupy badanej.

Dzień Chorób Rzadkich jest bliski dla 43 ankietowanych, mianowicie dla $15(10,07 \%)$ osób z grupy kontrolnej i $28(30,11 \%)$ z grupy badanej $(\mathrm{OR}=3,85 ; 95 \%$ CI $0,9-3,6$; $\left.\chi^{2}>\chi_{1 ; 0,001}^{2}, \mathrm{p}<0,001\right)$. W grupie badanej prawie połowa odpowiedzi twierdzących $(46,4 \%)$ wiązała się z chorobą osoby ankietowanej lub osoby bliskiej (rodzina, przyjaciele). Podobnie wielu ankietowanych nie podało powodu dla odpowiedzi twierdzącej. Jedna osoba uzasadniła swą pozytywną odpowiedź chęcią udzielania pomocy, a druga - faktem wykonywania zawodu lekarza. Natomiast w grupie kontrolnej 2 osoby motywowały przyjmowanie idei Dnia Chorób Rzadkich jako bliskiej, 1 motywowała chorobą własną oraz
1 - chorobą członka rodziny. Spośród ankietowanych z grupy kontrolnej, którzy uzasadnili swe pozytywne odpowiedzi na niniejsze pytanie, najliczniej - 4 osoby - reprezentowane były osoby posiadające chorych wśród znajomych.

\section{Dyskusja}

W ujęciu ogólnym problematyka chorób rzadkich jest znana niewielkiemu odsetkowi społeczeństwa. Przybliżają ją akcje informacyjne, jak np. DzChRz. Jak wynika z niniejszego badania, jego termin był znany kilkunastu procentom ankietowanych w obu grupach, bez istotnej statystycznie różnicy między obiema grupami. Na pytanie o termin Dnia Chorób Rzadkich znaczna część osób odpowiadała „dzisiaj”, co odnosiło się do 2 marca i mogło być spowodowane tym, że obchody Dnia Chorób Rzadkich były przeprowadzone w G.H. Turzyn w Szczecinie w sobotę 2 marca. Odpowiedzi te nie były zaliczone jako poprawne.

Definicja choroby rzadkiej ustalona przez Komisję Europejską ds. Zdrowia i Ochrony Konsumentów nie jest powszechnie znana. Podczas prób formułowania tej definicji część ankietowanych odnosiła się do częstości występowania i zwykle określała te choroby jako rzadko występujące. Nie podawano dokładnej częstości lub wskazywano częstość mniejszą niż jest przyjęta. Warty podkreślenia jest fakt, że częstość występowania chorób w populacji nie pojawiała się w treści każdej z podawanych definicji. Zwracano uwagę również na inne cechy chorób, które określano jako choroba wrodzona, uwarunkowana genetycznie lub trudna w leczeniu. Cechy te odnoszą się do aspektów biologicznych i medycznych, lecz nie epidemiologicznych.

Niniejsze badanie, mające na celu określenie niektórych aspektów wiedzy losowo wybranych przedstawicieli społeczeństwa na temat chorób o niskiej częstości występowania, ma charakter ogólny, jednak na podstawie wyników uzyskiwane są także informacje o powszechnej znajomości konkretnych nazw chorób z tej grupy. Nie wszystkie odpowiedzi udzielone na pytanie o trzy przykłady chorób rzadkich były poprawne. Wielokrotnie podawano jako odpowiedź „zespół Downa” (w grupie badanej 6,45\% i w grupie kontrolnej 4,7\%) oraz „stwardnienie rozsiane” (w obu grupach po 5,3\%). Ich częstość występowania to odpowiednio $1: 800-1000$ urodzeń i $1: 1000 \mathrm{w}$ populacji europejskiej. Z kolei fenyloketonuria, mukowiscydoza oraz zespół Turnera to choroby z pogranicza definicji choroby rzadkiej. Częstość występowania fenyloketonurii w Europie nie jest dokładnie znana, lecz jest szacowana na 1:15 000 urodzeń. Częstość występowania mukowiscydozy zawiera się w przedziale od $1: 10000$ do $1: 8000$, a częstość zespołu Turnera to $1: 5000$ urodzeń [8]. Pojedyncze osoby podały nazwy chorób bardzo rzadkich, np. zespół Di George’a i kwasicę glutarową typu I. Najczęściej wymieniana mukowiscydoza jest chorobą znaną dzięki badaniom przesiewowym i kampaniom społecznym. Inne choroby, nieobecne w przekazach medialnych, są mało znane. Często podawanym przykładem choroby rzadkiej 
była choroba moyamoya, co wyjaśnia fakt, że w tym okresie w pojazdach szczecińskiej komunikacji miejskiej ogłoszono prośbę o pomoc osobie chorej na tę chorobę. Pomimo wielu podanych przykładów chorób rzadkich i różnych jej definicji, wiedza na ich temat jest nadal znikoma oraz nieusystematyzowana. Wiele osób, które wiedziały o istnieniu Dnia Chorób Rzadkich, nie potrafiło wymienić ani jednego przykładu choroby rzadkiej $(34,8 \% \mathrm{w}$ grupie kontrolnej i $25,8 \% \mathrm{w}$ grupie badanej).

Znaczna część ankietowanych obu grup znała cel prowadzenia akcji takich jak DzChRz. Natomiast odsetek osób, dla których DzChRz ma duże znaczenie, był większy w grupie badanej niż w kontrolnej, co wiąże się $\mathrm{z}$ występowaniem choroby u osoby bliskiej i prawdopodobnie zwiększonym zainteresowaniem Dniem Chorób Rzadkich. Część badanych podczas wywiadów wyraziła chęć pomocy osobom chorym. Na uwagę zasługuje fakt, że 10\% osób z grupy kontrolnej przyznało, że $\mathrm{DzChRz}$ jest im bliski. Ten znaczny (w porównaniu z definicyjną częstością występowania choroby rzadkiej w populacji) odsetek ankietowanych wynika m.in. z faktu posiadania osób chorych w rodzinie lub wśród osób znajomych oraz dużej liczby chorób rzadkich w ogóle. Istnieje potrzeba informowania i edukowania na ten temat, aby każda osoba (niezwiązana z medycyną) wiedziała, jak zachować się w obliczu spotkania z osobą chorą, dzięki czemu nie będzie ona skazana na izolację i odrzucenie.

Podsumowując, istotne statystycznie różnice między grupą badaną a kontrolną zaobserwowano jedynie w zakresie wiedzy o obchodach Dnia Chorób Rzadkich oraz w fakcie określania idei Dnia Chorób Rzadkich jako bliskiej. Wynikają one z większego udziału osób związanych z problematyką chorób rzadkich w grupie badanej niż grupie kontrolnej. Niespodziewany jest brak istotnych różnic $\mathrm{w}$ odpowiedziach na pytania o wiedzę szczegółową w skali obu prób. Fakt ten wskazuje na potrzebę edukowania nie tylko społeczeństwa w ogóle, ale również osób chorych i ich rodzin.

Choć liczba badań naukowych w zakresie edukacji na temat chorób rzadkich jest niewielka, istnieje możliwość porównania wyników niniejszego badania z wynikami badania ankietowego „Świadomość europejska w zakresie rzadkich chorób" (European awareness of Rare Diseases) przeprowadzonego w 2010 r. we wszystkich państwach Unii Europejskiej. W badaniu tym zastosowano kwestionariusz z pytaniami zamkniętymi. Na uwagę zasługuje fakt, że w badaniu szczecińskim, opartym na pytaniach otwartych, które nie sugerują możliwości co do sposobu i treści odpowiedzi, podano definicje choroby rzadkiej, które odzwierciedlają spektrum odpowiedzi z badania ogólnoeuropejskiego. W badaniu tym większość ankietowanych wskazała częstość występowania chorób jako definiującą choroby rzadkie, ale również część respondentów określiła je jako choroby trudne w diagnozowaniu i leczeniu oraz choroby, które pozostają poza zakresem zainteresowania [9]. Z badania „Świadomość europejska w zakresie rzadkich chorób” wynika również, że $75 \%$ polskich respondentów zna chorobę o nazwie wrodzona łamliwość kości. Jest to najwyższy odsetek wśród populacji objętych tym badaniem i znacznie wyższy od drugiego z kolei, obliczonego dla populacji fińskiej, a wynoszącego 53\% [10]. W szczecińskim badaniu, z zastosowaniem pytania otwartego, wrodzona łamliwość kości nie należała do najczęstszych odpowiedzi.

Tłem do dalszych rozważań uwzględniających fakt posiadania osób bliskich chorujących na choroby rzadkie mogą być wyniki badania „Świadomość europejska w zakresie rzadkich chorób", które wykazują, że 43\% ankietowanych w Polsce i 40\% respondentów w UE ogółem nigdy nie słyszała o takich osobach. Wśród odpowiedzi twierdzących największy odsetek stanowiły te, które wskazywały na media jako źródło informacji (35\% w Unii Europejskiej ogółem i 37\% w Polsce). Łącznie wśród wszystkich badanych, osoby, które znają osobiście kogoś z chorobą rzadką stanowią 17\%, a udział tych, które słyszały o fakcie występowania choroby rzadkiej $\mathrm{w}$ rodzinie lub $\mathrm{w}$ gronie znajomych, to $13 \%$. W Polsce odpowiednio $13 \%$ i $9 \%$ [9].

Niniejsze badanie ankietowe zostało przeprowadzone podczas akcji „Dolina Mukolinków”, która jako jedno z wydarzeń programu XII Ogólnopolskiego Tygodnia Mukowiscydozy organizowanego przez Fundację Pomocy Rodzinom i Chorym na Mukowiscydozę MATIO jest przykładem szeroko zakrojonych działań o charakterze informacyjnym mającym na celu poprawę stanu zdrowia populacji. Program merytoryczny i kulturalny tego wydarzenia oraz targ pamiątek wzbudziły zainteresowanie wielu klientów G.H. Turzyn, a także osób, które przybyły z zamiarem uczestnictwa w akcji. Sukces organizacyjny podobnego wydarzenia w Tokio opisali uczestnicy $6^{\text {th }}$ International Conference on Rare Diseases and Orphan Drugs w Buenos Aires. Japońską imprezę organizowaną w 2010 r. po raz pierwszy odwiedziło 300 osób, $40 \%$ z nich było związanych z pacjentami z chorobami rzadkimi lub trudnymi, a $60 \%$ stanowiły osoby postronne [11]. Dzień Chorób Rzadkich jest okazją do prowadzenia badań socjologicznych. Wnioski z tych badań mogą stać się argumentami w dyskusji nad opieką nad chorymi.

\section{Wnioski}

1. Większość uczestników akcji „Dolina Mukolinków” wiedziała o istnieniu Dnia Chorób Rzadkich.

2. Nie wykazano istotnej statystycznie różnicy między znajomością terminu Dnia Chorób Rzadkich wśród respondentów z grupy badanej i grupy kontrolnej.

3. Wiele osób, które wiedziały o istnieniu Dnia Chorób Rzadkich, nie potrafiło wymienić ani jednego przykładu choroby rzadkiej, zatem ważne jest przedstawianie tych chorób w kampaniach informacyjnych.

4. Ankietowani najlepiej znali najczęstsze $\mathrm{z}$ chorób rzadkich. 
5. Zespół Downa, choć nie należy do chorób rzadkich, był jednym z najczęściej wymienianych przykładów.

6. Cel Dnia Chorób Rzadkich formułowany przez ankietowanych był zgodny z przyjętym przez organizatorów.

7. Znaczny (w porównaniu $\mathrm{z}$ definicyjną częstością występowania choroby rzadkiej w populacji) odsetek ankietowanych z grupy kontrolnej, którzy określili Dzień Chorób Rzadkich jako bliski (10\%), wynika z dużej liczby chorych oraz faktu posiadania osób chorych w rodzinie lub wśród osób znajomych.

8. Efektem kampanii informacyjnej prowadzonej w Dniu Chorób Rzadkich jest popularyzacja interdyscyplinarnej problematyki chorób rzadkich. Prezentowana w niewielkim stopniu szczegółowa wiedza o chorobach rzadkich wskazuje na potrzebę prowadzenia dalszych wysiłków edukacyjnych.

\section{Piśmiennictwo}

1. European Comission Health \& Consumer Protection Directorate-General: Useful information on Rare Diseases from an EU perspective. $\mathrm{JMO} / \mathrm{C} 5 / 81$.
2. Dodge J.A., Chigladze T., Donadieu J., Grossman Z., Ramos F., Serlicorni A. et al:: The importance of rare diseases: from the gene to society. Arch Dis Child. 2011, 96 (9), 791-792.

3. Simerka P.: Council recommendation of 8 June 2009 on an action in the field of rare diseases. Official Journal of the European Union 3.7.2009: C151/7-10.

4. Skoczylas M., Rudnicki J., Czeszyńska M.B., Konefat H., Kordek A., Łoniewska B. et al.: Teaching of medical students and young doctors in the field of rare diseases. Lietuvos Pediatrijos Kronika. 2011, 3, 24-26.

5. Kampania „Nadzieja. Mamy ją w genach”. http://www.nadziejawgenach.pl/ (21.03.2014).

6. Orpha.net. The portal for rare diseases and orphan drugs. www.orpha. net (21.03.2014)

7. Rare Disease Day. http://www.rarediseaseday.org/ (21.03.2014).

8. Orpha.net. http://www.orpha.net (21.12.2014).

9. Świadomość europejska w zakresie rzadkich chorób. http://ec.europa.eu/ public_opinion/archives/eb_special_379_360_en.htm (31.03.2014).

10. Special Eurobarometer 361. European awareness of Rare Diseases. Report. http://ec.europa.eu/public_opinion/archives/eb_special_379_360_ en.htm (31.03.2014).

11. Nishimura Y., Mimoto F., Ohno K., Terada Y.: Rare Disease Day 2010 in Japan: $1^{\text {st }}$ Japanese Rare Disease Day event. In: $6^{\text {th }}$ International Conference on Rare Diseases and Orphan Drugs. Global Approaches to Research and Patients Access to Diagnosis, Information and Care, And the Common Issues with Neglected Diseases in Developing Countries. Program and Abstract Book. March 18-20, 2010. Buenos Aires - Argentina. Buenos Aires: International Conferences for Rare Diseases and Orphan Drugs. 2010, 59-60. http://icord.se/past-events/buenos_aires_2010 (21.03.2014). 